\title{
HYPERSENSITIVITY OF YOUNG PIGLETS TO ESCHERICHIA COLI ENDOTOXIN
}

\author{
B. J. Shreeve AND J. R. Thomlinson \\ Department of Veterinary Pathology, University of Liverpool
}

\section{Plate XVII}

EXPERIMENTS described in an earlier paper (Shreeve and Thomlinson, 1970a) have shown that sows immunised with hen-egg albumin may confer hypersensitivity on their piglets by means other than through the colostrum, and it was postulated that, in some circumstances, small amounts of maternal antibody may cross the placental barrier and cause hypersensitivity in the newly born piglet. It was also shown that antibody acquired from colostrum was capable of conferring passive hypersensitivity. The symptoms and lesions that developed in hypersensitive piglets after challenge with egg albumin closely resembled those that occur in natural cases of disease associated with Escherichia coli. The purpose of the experiments described in the present paper was to determine whether a similar sensitisation of piglets may be induced by the prior administration of $E$. coli antigens to their pregnant parent sows.

\section{MATERIALS AND METHODS}

Origin of animals and collection of samples. Pregnant Large White sows were obtained from the same source as those used in the earlier experiments and samples of serum and colostral whey were obtained by the methods described previously (Shreeve and Thomlinson, $1970 a$ ). At parturition, piglets from normal and immunised sows for the "colostrumdeprived " experimental groups were removed immediately from their dams and housed separately. Piglets for the " colostrum-fed" experimental groups remained with their dams and were allowed to suck for $24 \mathrm{hr}$.

Preparation of E. coli extract for immunisation and challenge. A crude frozen and thawed lysate containing endotoxic material was produced from E. coli serotype O138:K81(B) by the method of Erskine, Sojka and Lloyd (1957) and stored at $-30^{\circ} \mathrm{C}$. The same batch of extract was used throughout the experiments.

Immunisation of sows. The $E$. coli extract was diluted 10 -fold in sterile normal saline and intravenous injections of $1 \mathrm{ml}, 2 \mathrm{ml}, 3 \mathrm{ml}$ and $4 \mathrm{ml}$ were given at $48-\mathrm{hr}$ intervals. This course of injections was repeated after an interval of 10 days. After a further 10 days, a similar course of $0.5 \mathrm{ml}, 0.75 \mathrm{ml}$ and $1.0 \mathrm{ml}$ of undiluted extract was given, the last dose being given 10 days before the expected date of parturition. A further dose of $2 \mathrm{ml}$ was given within $2 \mathrm{hr}$ before parturition. This last dose caused mild symptoms of shock, with hyperpnoea and hyperaemia of the skin of the extremities, which lasted for approximately 2 min.

Intradermal tests in piglets. The sites and techniques for intradermal tests on colostrumdeprived and colostrum-fed piglets from normal and immunised sows were as described previously (Shreeve and Thomlinson, 1970a). The E. coli O138:K81(B) extract was diluted 
100-fold in sterile normal saline and used in doses of $0.1 \mathrm{ml}$. Control injections of normal saline were given at comparable sites.

Intravenous and oral challenges. When the intradermal tests were completed, piglets were challenged intravenously by injecting $1 \mathrm{ml}$ or $3 \mathrm{ml}$ of $E$. coli extract diluted 5-fold in sterile normal saline into the anterior vena cava. As a control, a total of eight piglets, two from each experimental group, were given an intravenous injection of normal saline in 1-ml and 3-ml amounts. Other piglets which had not been subjected to intradermal tests were challenged orally by introducing $2 \mathrm{ml}$ of similarly diluted $E$. coli extract slowly into the posterior part of the buccal cavity. Two colostrum-deprived piglets for this experiment were passively sensitised by injecting intravenously $3 \mathrm{ml}$ of an $E$. coli $0138: \mathrm{K} 81$ (B) pig antiserum $48 \mathrm{hr}$ before they were challenged.

Serological methods. The haemagglutination and antiglobulin haemagglutination tests were used as described by Buxton and Thomlinson (1961) to detect antibodies to $E$. coli in sow and piglet serum.

Histological methods. All except two piglets were killed for necropsy by stunning and exsanguination $2 \mathrm{hr}$ after intravenous or oral challenge. The other two piglets were similarly killed $1 \mathrm{hr}$ after challenge. Immediately after the piglets were killed, portions of skin from the intradermal test sites, lung, heart, liver, stomach, intestine and mesenteric lymph-node were fixed in 4 per cent. formaldehyde in saline and embedded in paraffin wax. Sections $5 \mu \mathrm{m}$ thick were stained with haematoxylin and eosin.

Bacteriological examinations. Cultures were made from samples taken post mortem from intestinal contents, heart blood, liver, spleen, lung and kidney and these were examined for the presence of pathogenic $E$. coli serotypes as previously described (Shreeve and Thomlinson, 1970a). In addition, similar cultural examinations were made on faeces samples taken from the sows when they were received on the premises and at intervals during the course of the experiments.

\section{RESULTS}

\section{Studies with colostrum-deprived piglets}

\section{Effects of intradermal challenge}

The results of intradermal tests on colostrum-deprived piglets from five normal sows and from four immunised sows are compared in table I. No skin reactions developed in the piglets from two of the normal sows. Only two piglets, both from one of the normal sows, developed skin reactions within $60 \mathrm{~min}$. These were in the range 4-7 mm, but had increased in size at $90 \mathrm{~min}$. Two other piglets showed reactions in excess of $4-7 \mathrm{~mm}$ and these were evident at $120 \mathrm{~min}$. The reactions were oedematous and showed slight erythema. Eight of the 14 piglets from immunised sows showed skin reactions of at least $8 \mathrm{~mm}$ at $60 \mathrm{~min}$. and all except one of the remainder had developed similar reactions at $90 \mathrm{~min}$. (table I). In some instances, the reactions increased in size after 90 min., but in all the piglets from one of the sows (sow 6492) they regressed. Oedema and some erythema were observed. No reactions occurred at the sites of the normal saline injections in either group.

\section{Effects of intravenous challenge}

The severity of reactions that developed after intravenous challenge in colostrum-deprived piglets from five normal and three immunised sows is indicated in table II. In the group from normal sows, only three piglets that had received a 3-ml challenge dose developed immediate reactions, and in the 
majority of piglets from this group signs did not develop until $30 \mathrm{~min}$. after challenge. The signs included incoordination, trembling, hyperpnoea, persistent crossing of the front legs and a falsetto squeak. In five of the piglets,

TABLE I

Dermal reactions to Escherichia coli $0138: K 81(B)$ extract in colostrum-deprived piglets from normal and immunised sows

\begin{tabular}{|c|c|c|c|c|c|c|c|}
\hline \multicolumn{3}{|c|}{ Data relating to parent sow } & \multirow{3}{*}{$\begin{array}{c}\text { Piglet } \\
\text { number }\end{array}$} & \multirow{2}{*}{\multicolumn{4}{|c|}{$\begin{array}{l}\text { Dermal reaction } \dagger \text { at stated time } \\
\text { after injection (min.) }\end{array}$}} \\
\hline \multirow{2}{*}{$\begin{array}{l}\text { Category and } \\
\text { identity number }\end{array}$} & \multicolumn{2}{|c|}{$\underset{\text { titre* }}{\text { Serum antibody }}$} & & & & & \\
\hline & HA & AG & & 30 & 60 & 90 & 120 \\
\hline Normal 6337 & 20 & 40 & 1 & - & - & - & ++ \\
\hline Normal 97 & 10 & 20 & $\begin{array}{l}1 \\
2\end{array}$ & $\overline{-}$ & 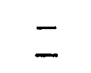 & 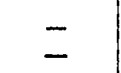 & $\overline{-}$ \\
\hline Normal 99 & 20 & 160 & $\begin{array}{l}3 \\
6\end{array}$ & $\overline{-}$ & $\begin{array}{l}+ \\
+\end{array}$ & $\begin{array}{l}++ \\
++\end{array}$ & $\begin{array}{l}++ \\
++\end{array}$ \\
\hline Normal 6900 & 20 & 160 & $\begin{array}{l}11 \\
13 \\
14\end{array}$ & $\begin{array}{l}\overline{-} \\
-\end{array}$ & $\overline{-}$ & $\begin{array}{l}+ \\
+\end{array}$ & $+\overline{+}+$ \\
\hline Normal 6493 & 20 & 40 & $\begin{array}{l}1 \\
2 \\
3\end{array}$ & $\bar{z}$ & $\begin{array}{l}- \\
-\end{array}$ & $\begin{array}{l}- \\
-\end{array}$ & $\bar{z}$ \\
\hline Immunised 6492 & 1280 & 10240 & $\begin{array}{r}3 \\
4 \\
6 \\
8 \\
9 \\
10\end{array}$ & $\begin{array}{l}\bar{z} \\
\bar{z} \\
\overline{-}\end{array}$ & $\begin{array}{c}++ \\
+++ \\
+++ \\
- \\
++ \\
-\end{array}$ & $\begin{array}{c}++ \\
++ \\
+++ \\
+++ \\
+++ \\
+++\end{array}$ & $\begin{array}{l}z \\
z \\
z \\
z\end{array}$ \\
\hline Immunised 6000 & 320 & 1280 & $\begin{array}{l}1 \\
2 \\
3\end{array}$ & $\bar{z}$ & $\begin{array}{l}++ \\
++ \\
++\end{array}$ & $\begin{array}{c}+++ \\
++++ \\
+++\end{array}$ & $\begin{array}{c}++++ \\
++++ \\
+++\end{array}$ \\
\hline Immunised 6129 & 1280 & 10240 & $\begin{array}{l}3 \\
5 \\
6\end{array}$ & $\bar{z}$ & $\underline{+}$ & $\begin{array}{c}+++ \\
++ \\
++\end{array}$ & $\begin{array}{c}++++ \\
+++ \\
+++\end{array}$ \\
\hline Immunised 6838 & 1280 & 10240 & $\begin{array}{l}3 \\
4\end{array}$ & $\bar{t}$ & + & $\begin{array}{c}++ \\
+\end{array}$ & +++ \\
\hline
\end{tabular}

* $\mathrm{HA}=$ Haemagglutination; $\mathrm{AG}=$ antiglobulin haemagglutination .

$\dagger-=$ No reaction; $+=4-7 \mathrm{~mm} ;++=8-11 \mathrm{~mm} ;+++=12-15 \mathrm{~mm} ;++++=$ 16-22 mm.

the reactions became progressively more severe and these piglets developed vomiting and diarrhoea at 30-120 min.

In all ten piglets from the immunised sows, incoordination, trembling and hyperpnoea developed immediately (table II). The severity of the symptoms increased until all except one of the piglets vomited and developed diarrhoea 
within $60 \mathrm{~min}$. after challenge. No symptoms were observed in control piglets that received injections of normal saline.

\section{Serological findings}

No antibodies were detected in serum samples from any of the colostrumdeprived piglets. The serum antibody titres of the normal and immunised sows are shown in table I.

TABLE II

Severity of reactions in colostrum-deprived piglets from normal and immunised sows after intravenous challenge with $E$. coli $O 138: K 81(B)$ extract diluted 1 in 5

\begin{tabular}{|c|c|c|c|c|c|c|}
\hline \multirow{2}{*}{$\begin{array}{l}\text { Category and identity } \\
\text { number or letter } \\
\text { of parent sow }\end{array}$} & \multirow{2}{*}{$\begin{array}{l}\text { Piglet } \\
\text { number }\end{array}$} & \multirow{2}{*}{$\begin{array}{l}\text { Challenge } \\
\text { dose } \\
(\mathrm{ml})\end{array}$} & \multicolumn{4}{|c|}{$\begin{array}{l}\text { Severity of reaction* at stated time } \\
\text { after challenge (min.) }\end{array}$} \\
\hline & & & 0 & 30 & 60 & 120 \\
\hline Normal 6337 & 1 & 1 & - & + & ++ & ++ \\
\hline Normal B & $\begin{array}{l}1 \\
2\end{array}$ & $\begin{array}{l}1 \\
1\end{array}$ & - & $\begin{array}{l}+ \\
+\end{array}$ & $\begin{array}{l}+ \\
+\end{array}$ & $\begin{array}{c}++ \\
+\end{array}$ \\
\hline Normal 6900 & 3 & 1 & - & + & + & ++ \\
\hline Normal 6658 & $\begin{array}{l}1 \\
2 \\
3\end{array}$ & $\begin{array}{l}3 \\
3 \\
3\end{array}$ & $\begin{array}{l}+ \\
+ \\
+\end{array}$ & $\begin{array}{l}+ \\
++ \\
++\end{array}$ & $\begin{array}{l}+ \\
++ \\
++\end{array}$ & $\begin{array}{l}+ \\
++ \\
++\end{array}$ \\
\hline Normal 6639 & $\begin{array}{l}1 \\
2 \\
3 \\
4 \\
5 \\
9\end{array}$ & $\begin{array}{l}3 \\
3 \\
3 \\
3 \\
3 \\
3\end{array}$ & $\begin{array}{l}- \\
- \\
- \\
- \\
-\end{array}$ & $\begin{array}{l}+ \\
+ \\
+ \\
+ \\
+ \\
+\end{array}$ & $\begin{array}{l}+ \\
+ \\
+ \\
+ \\
+ \\
+\end{array}$ & $\begin{array}{l}+ \\
+ \\
+ \\
+ \\
+ \\
+\end{array}$ \\
\hline Immunised 6492 & $\begin{array}{r}3 \\
6 \\
8 \\
9 \\
10\end{array}$ & $\begin{array}{l}1 \\
1 \\
1 \\
1 \\
1\end{array}$ & $\begin{array}{l}+ \\
+ \\
+ \\
+ \\
+\end{array}$ & $\begin{array}{c}++ \\
+ \\
+ \\
+ \\
++\end{array}$ & $\begin{array}{c}++ \\
++ \\
++ \\
+ \\
++\end{array}$ & $\begin{array}{c}++ \\
++ \\
++ \\
+ \\
++\end{array}$ \\
\hline Immunised 6000\{ & $\begin{array}{l}1 \\
2 \\
3\end{array}$ & $\begin{array}{l}1 \\
1 \\
1\end{array}$ & $\begin{array}{l}+ \\
+ \\
+\end{array}$ & $\begin{array}{l}t \\
+ \\
+\end{array}$ & $\begin{array}{l}++ \\
++ \\
++\end{array}$ & $\begin{array}{l}\ldots \dagger \\
\ldots \dagger \\
+\dagger\end{array}$ \\
\hline Immunised 6129\{ & $\begin{array}{l}5 \\
6\end{array}$ & $\begin{array}{l}1 \\
1\end{array}$ & $\begin{array}{l}+ \\
+\end{array}$ & $\begin{array}{l}+ \\
+\end{array}$ & $\begin{array}{l}++ \\
++\end{array}$ & $\begin{array}{l}++ \\
++\end{array}$ \\
\hline
\end{tabular}

$*-=$ Negative $+=$ mild (incoordination, trembling, hyperpnoea) $++=$ moderate (vomiting, diarrhoea); $+++=$ severe (collapse).

$\uparrow$ Killed for necropsy at $60 \mathrm{~min}$.

\section{Studies with colostrum-fed piglets}

Effects of intradermal challenge

Skin reactions were observed in four of the six piglets from three normal sows (table III). These reactions varied in their severity and time of onset, the most severe being in two piglets from the same sow. 
All the piglets from the three immunised sows developed skin reactions (table III). In the piglets from one of the sows, reactions of 8-11 mm developed within $30 \mathrm{~min}$. In those from the other two sows, reactions were first evident at $60 \mathrm{~min}$., but some were at least $16 \mathrm{~mm}$ in diameter at this time. Most of these reactions persisted throughout the period of observation. Marked erythema was present in the lesions. No reactions were observed at the sites of normal saline injections in either of the two groups of piglets.

TABLE III

Dermal reactions to $E$. coli $0138: K 81(B)$ extract in colostrum-fed piglets from normal and immunised sows

\begin{tabular}{|c|c|c|c|c|c|c|c|}
\hline \multirow{3}{*}{$\begin{array}{l}\text { Category and } \\
\text { identity number } \\
\text { of parent sow }\end{array}$} & \multicolumn{3}{|c|}{ Piglet } & \multirow{2}{*}{\multicolumn{4}{|c|}{$\begin{array}{l}\text { Dermal reaction }{ }^{\text {injection }(\mathrm{min} .)} \\
\text { at stated time after }\end{array}$}} \\
\hline & \multirow{2}{*}{ Number } & \multicolumn{2}{|c|}{$\begin{array}{l}\text { Serum } \\
\text { antibody titre* }\end{array}$} & & & & \\
\hline & & HA & $\mathrm{AG}$ & 30 & 60 & 90 & 120 \\
\hline Normal 6337\{ & $\begin{array}{l}4 \\
5\end{array}$ & $\begin{array}{r}10 \\
5\end{array}$ & $\begin{array}{r}10 \\
5\end{array}$ & $\overline{-}$ & $\begin{array}{l}++ \\
++\end{array}$ & $\begin{array}{l}++ \\
++\end{array}$ & $\overline{+}+$ \\
\hline Normal 99 & 1 & 5 & 40 & + & + & + & + \\
\hline Normal 6931\{ & $\begin{array}{l}4 \\
5 \\
6\end{array}$ & $\begin{array}{l}5 \\
\ldots \ddagger \\
\cdots\end{array}$ & $\begin{array}{l}10 \\
\cdots \\
\cdots\end{array}$ & $\bar{z}$ & $\bar{z}$ & $\begin{array}{l}+ \\
-\end{array}$ & $\bar{z}$ \\
\hline Immunised 6492 & $\begin{array}{r}1 \\
2 \\
5 \\
11\end{array}$ & $\begin{array}{r}640 \\
1280 \\
1280 \\
640\end{array}$ & $\begin{array}{r}5120 \\
10240 \\
5120 \\
5120\end{array}$ & $\begin{array}{l}\bar{z} \\
\overline{-}\end{array}$ & $\begin{array}{c}++++ \\
+++t \\
++ \\
+++\end{array}$ & $\begin{array}{c}+++t \\
+++t \\
++ \\
++t\end{array}$ & $\begin{array}{c}+++ \\
+++ \\
+++ \\
++\end{array}$ \\
\hline Immunised 6129 & 2 & 640 & 1280 & - & ++ & ++ & $++t$ \\
\hline Immunised 6838\{ & $\begin{array}{l}7 \\
8 \\
9\end{array}$ & $\begin{array}{l}160 \\
320\end{array}$ & $\begin{array}{l}1280 \\
2560\end{array}$ & $\begin{array}{l}++ \\
++ \\
++\end{array}$ & $\begin{array}{l}++ \\
+++ \\
+++\end{array}$ & $\begin{array}{l}++ \\
++ \\
++\end{array}$ & $\begin{array}{c}++ \\
++ \\
+++\end{array}$ \\
\hline
\end{tabular}

* HA = Haemagglutination; $\mathrm{AG}=$ antiglobulin haemagglutination.

$+-=$ No reaction; $t=4-7 \mathrm{~mm} ;++=8-11 \mathrm{~mm} ;+++=12-15 \mathrm{~mm} ;++++=$ 16-22 $\mathrm{mm}$.

$\ddagger \ldots=$ Test not done.

\section{Effects of intravenous challenge}

Mild reactions developed in all the piglets from the four normal sows (table IV) and were similar to those observed in the colostrum-deprived piglets from the immunised sows except that no vomiting or diarrhoea occurred. In two of the piglets, these symptoms did not develop until $120 \mathrm{~min}$. after challenge.

Only five of the seven piglets from immunised sows developed signs. In three of these piglets, the reactions were severe and developed immediately after challenge. In all cases, they were followed by a relatively rapid recovery. 
Severely affected piglets collapsed and breathing stopped for a few seconds. Hyperpnoea then occurred, and vomiting, diarrhoea, incoordination of the limbs and recurrent bouts of trembling followed. No symptoms developed in control piglets given injections of normal saline.

\section{Serological findings}

Table IV shows the serum antibody titres in the colostrum-fed piglets from both groups of sows.

TABLE IV

Severity of reactions in colostrum-fed piglets from normal and immunised sows after intravenous challenge with $1 \mathrm{ml} \mathrm{E}$. coli $O 138: K 81(B)$ extract diluted 1 in 5

\begin{tabular}{|c|c|c|c|c|c|c|c|}
\hline \multirow{2}{*}{$\begin{array}{l}\text { Category and } \\
\text { identity number } \\
\text { of parent sow }\end{array}$} & \multirow{2}{*}{$\begin{array}{l}\text { Piglet } \\
\text { number }\end{array}$} & \multicolumn{2}{|c|}{$\begin{array}{l}\text { Serum } \\
\text { antibody titre* }\end{array}$} & \multicolumn{4}{|c|}{$\begin{array}{l}\text { Severity of symptoms } \dagger \text { at stated } \\
\text { time after challenge (min.) }\end{array}$} \\
\hline & & HA & AG & 0 & 30 & 60 & 120 \\
\hline Normal 6337\{ & $\begin{array}{l}4 \\
5\end{array}$ & $\begin{array}{r}10 \\
5\end{array}$ & $\begin{array}{r}10 \\
5\end{array}$ & $\overline{-}$ & $\overline{-}$ & - & + \\
\hline Normal 99 & 1 & 5 & 40 & + & + & + & + \\
\hline Normal 6639\{ & $\begin{array}{l}11 \\
12\end{array}$ & $\ldots \ddagger$ & $\begin{array}{l}\cdots \\
\cdots\end{array}$ & + & + & + & + \\
\hline Normal 6931\{ & $\begin{array}{l}1 \\
4\end{array}$ & $\dddot{5}$ & 10 & + & $\overline{+}$ & $\overline{+}$ & $\overline{+}$ \\
\hline Immunised 6492 & $\begin{array}{r}1 \\
2 \\
5 \\
11 \\
12 \\
13\end{array}$ & $\begin{array}{r}640 \\
1280 \\
1280 \\
640 \\
640 \\
640\end{array}$ & $\begin{array}{r}5120 \\
10240 \\
5120 \\
5120 \\
1280 \\
1280\end{array}$ & $\begin{array}{c}- \\
\overline{+} \\
++ \\
+++ \\
+ \\
+\end{array}$ & $\begin{array}{c}- \\
\overline{+} \\
++ \\
\overline{+}\end{array}$ & $\begin{array}{c}- \\
+ \\
++ \\
- \\
-\end{array}$ & $\begin{array}{l}- \\
+ \\
+ \\
- \\
-\end{array}$ \\
\hline Immunised 6129 & 2 & 640 & 1280 & $++t$ & + & + & + \\
\hline
\end{tabular}

* $\mathrm{HA}=$ Haemagglutination; $\mathrm{AG}=$ antiglobulin haemagglutination.

$+-=$ Negative; $+=$ mild; $++=$ moderate; $+t+=$ severe.

$\ddagger \ldots=$ test not done.

\section{Effects of oral challenge}

Four colostrum-deprived piglets from two normal sows developed mild symptoms $6 \mathrm{~min}$. after challenge and these persisted throughout the period of observation (table V). The two colostrum-fed piglets from the normal sow, the two passively sensitised piglets and the two colostrum-deprived piglets from the immunised sow all developed symptoms of the same order and recovered after $60 \mathrm{~min}$. In the colostrum-fed piglets from the immunised sow, the symptoms were severe and recovery occurred more rapidly. 


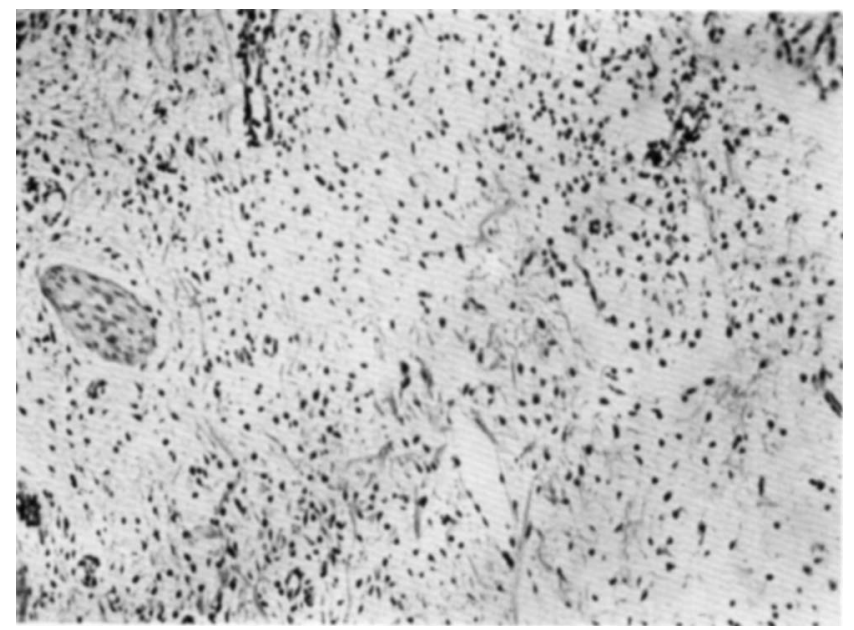

FIG. 1.-Dermal reaction in a colostrum-deprived piglet from a normal sow after intradermal challenge with $0.1 \mathrm{ml}$ of an extract of Escherichia coli $\mathrm{O} 138: \mathrm{K} 81(\mathrm{~B})$. Haematoxylin and eosin (HE). $\times c .25$.

FIG. 2.--Dermal reaction in a colostrum-deprived piglet from an immunised sow after intradermal challenge with $0.1 \mathrm{ml}$ E. coli O138:K81(B) extract. HE. $\times c .25$.
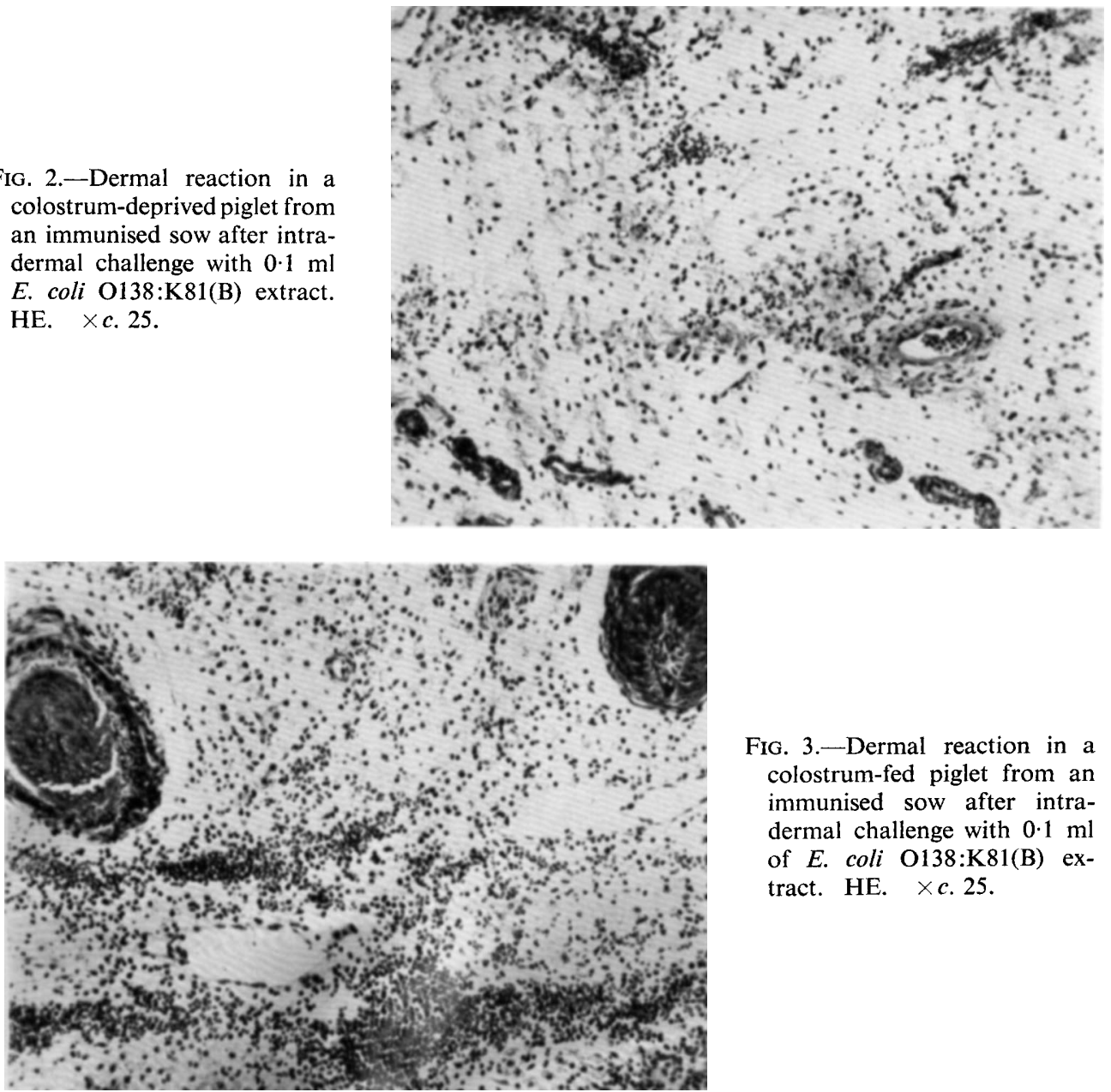

FIG. 3.-Dermal reaction in a colostrum-fed piglet from an immunised sow after intradermal challenge with $0.1 \mathrm{ml}$ of $E$. coli O138:K81(B) extract. HE. $\times$ c. 25 . 


\section{Gross lesions}

\section{Observations on piglets from normal sows}

Colostrum-deprived piglets. Oedema was present in the ventral abdominal wall, the mesocolon, the gall bladder wall, the portal area of the liver, the lesser curvature of the stomach, and the portal, gastric and mesenteric lymph-nodes. No gross changes were observed in the intestinal mucosa. In addition, in the

TABLE V

Severity of reactions in colostrum-deprived, colostrum-fed and passively sensitised piglets after oral challenge with $2 \mathrm{ml} \mathrm{E}$. coli $0138: K 81(B)$ extract diluted 1 in 5

\begin{tabular}{|c|c|c|c|c|c|}
\hline \multirow{2}{*}{$\begin{array}{l}\text { Category and } \\
\text { identity number } \\
\text { of parent sow }\end{array}$} & \multirow{2}{*}{$\begin{array}{l}\text { History and number } \\
\text { of test piglet }\end{array}$} & \multicolumn{4}{|c|}{$\begin{array}{l}\text { Severity of reaction* at stated time } \\
\text { after challenge (min.) }\end{array}$} \\
\hline & & 6 & 30 & 60 & 120 \\
\hline Normal 6900 & $\begin{array}{c}\text { Colostrum- } \\
\text { deprived }\end{array}\left\{\begin{array}{l}13 \\
14\end{array}\right.$ & + & + & + & $\stackrel{+}{+}$ \\
\hline Normal 6493 & $\begin{array}{l}\text { Colostrum- } \\
\text { deprived }\end{array}\left\{\begin{array}{l}3 \\
6\end{array}\right.$ & + & + & $\begin{array}{l}+ \\
+\end{array}$ & $\begin{array}{l}+ \\
+\end{array}$ \\
\hline Normal 6931 & $\begin{array}{c}\text { Colostrum- } \\
\text { fed }\end{array}\left\{\begin{array}{l}5 \\
6\end{array}\right.$ & $\begin{array}{l}++ \\
++\end{array}$ & + & + & $\overline{-}$ \\
\hline Normal 6493 & $\underset{\text { sensitised }}{\text { Passively }}\left\{\begin{array}{l}4 \\
5\end{array}\right.$ & $\begin{array}{l}++ \\
++\end{array}$ & $\begin{array}{l}++ \\
++\end{array}$ & $\begin{array}{l}++ \\
++\end{array}$ & $\overline{-}$ \\
\hline Immunised 6838 & $\begin{array}{l}\text { Colostrum- } \\
\text { deprived }\end{array}\left\{\begin{array}{l}3 \\
4\end{array}\right.$ & $\begin{array}{l}++ \\
++\end{array}$ & $\begin{array}{l}++ \\
++\end{array}$ & $\begin{array}{l}++ \\
++\end{array}$ & $\overline{+}$ \\
\hline Immunised 6838 & $\underset{\text { Cod }}{\text { Colostrum- }}\left\{\begin{array}{l}5 \\
7 \\
9\end{array}\right.$ & $\begin{array}{l}+++ \\
+++ \\
+++\end{array}$ & $\begin{array}{l}+ \\
+ \\
+\end{array}$ & $\begin{array}{l}z \\
z\end{array}$ & $\bar{z}$ \\
\hline
\end{tabular}

piglets that were challenged orally, an excess of clear pericardial fluid was present, and areas of haemorrhage were observed on the parietal surface of the liver and in the gall bladder wall.

Colostrum-fed piglets. In the piglets challenged intravenously, the lesions were similar to those of the colostrum-deprived group. In addition, congestion of the lungs and spleen occurred in one piglet and subserous oedema affecting the ureters was observed in another. In the group challenged by the oral route, one piglet showed no gross lesions and another had areas of haemorrhage in the lungs and on both ventricles of the heart.

\section{Observations on piglets from immunised sows}

Colostrum-deprived piglets. Oedema was present in the stomach wall in the region of the greater curvature as well as in the sites described above. In 
some of the more severely affected piglets, marked subserous oedema was present surrounding the kidneys and ureters. The mesenteric lymphatic vessels were dilated. The pleural and pericardial cavities contained an excess of clear fluid, and petechial haemorrhages were present on the ventricles of the heart. The mesenteric lymph-nodes and spleen were congested. No lesions were observed in the intestinal mucosa. Similar lesions were observed in the two piglets killed $60 \mathrm{~min}$. after challenge, except that the greater curvature of the stomach wall was unaffected and there was no oedema surrounding the kidneys and ureters. In the two piglets that were challenged orally, the small intestine contained a greater quantity of fluid material and the mesenteric blood vessels were congested. Excess clear pericardial fluid was present.

Colostrum-fed piglets. No gross lesions were observed in the piglets challenged by the intravenous route. In the three piglets challenged orally, slight oedema was present in the portal area of the liver, the mesocolon and the subperitoneal tissue surrounding the ureters. Petechial haemorrhages were present on the ventricles of the heart and, in two of the piglets, the lungs were congested. The lumen of the small intestine contained a relatively large amount of a yellow fluid.

\section{Histological findings}

\section{Observations on piglets from normal sows}

Skin reactions. In colostrum-deprived piglets, a few scattered neutrophils are present (fig. 1). In colostrum-fed piglets, these lesions show slight haemorrhage. Neutrophils are present in small clusters.

Lungs. In colostrum-deprived piglets, oedema and haemorrhage are present in the interlobular septa. Interlobular oedema is also evident in the colostrumfed group, but there is no haemorrhage; there are areas of emphysema.

Heart. In colostrum-fed piglets, there are areas of haemorrhage in the myocardium.

Liver. Lymphatic vessels in the region of the portal tracts are engorged in the colostrum-deprived piglets that had been challenged orally. Lymphocytes and neutrophils are numerous in these areas. Similar cellular infiltrations are present in the livers of the colostrum-fed piglets.

Stomach. Lymphocytes are numerous in the oedematous lesions in colostrum-deprived piglets that had been challenged orally.

Intestine. In colostrum-fed piglets that had been challenged orally, eosinophils are numerous in the submucosa of the ileum.

Mesenteric lymph-nodes. Eosinophils are numerous in the cortices of these nodes in colostrum-deprived piglets.

\section{Observations on piglets from immunised sows}

Skin reactions. In the colostrum-deprived piglets, large numbers of neutrophils occur in clusters, often near blood vessels (fig. 2). In the colostrum-fed piglets, areas of haemorrhage are prominent. Much oedema is present and, 
in addition to clusters of neutrophils, macrophages are numerous (fig. 3). Some lymphocytes and eosinophils are also present.

Lungs. Oedema of interlobular septa and slight peribronchial oedema are evident in sections from colostrum-fed piglets that were challenged intravenously, and congestion is marked in sections from those that were challenged orally.

Heart. Foci of myocardial haemorrhage are present in colostrum-deprived piglets.

Liver. In all piglets from immunised sows, areas of haemorrhage occur in the liver parenchyma and lymphatic vessels are engorged in the region of the portal tracts. In colostrum-deprived piglets, oedema and haemorrhage occur in the gall bladder wall. Neutrophils and lymphocytes are numerous in this lesion.

Stomach. In colostrum-deprived piglets, eosinophils, neutrophils and free red blood cells are numerous in the areas of submucosal oedema of the greater curvature. The oedema infiltrates the muscular layer and there is subserosal oedema at the lesser curvature. Submucous oedema is evident at the greater curvature of the stomach in the colostrum-fed piglets also.

Intestine. In colostrum-deprived piglets, lymphocytes and eosinophils are numerous in the oedematous areas of the spiral colon. In all piglets that were challenged by the oral route, eosinophils are numerous in the lamina propria and submucosa of the ileum.

Mesenteric lymph-nodes. In both colostrum-deprived and colostrum-fed groups of piglets, the subcapsular lymphatics are dilated. Oedema is present and eosinophils are numerous in the cortex. Neutrophils are numerous in the colostrum-fed piglets.

\section{Bacteriological findings}

No pathogenic serotypes of $E$. coli were found in cultures prepared from organs or intestinal contents from piglets at necropsy. Haemolytic Escherichia coli $\mathrm{O} 138: \mathrm{K} 81(\mathrm{~B})$ was occasionally present in very small numbers in samples of faeces from the sows.

\section{Discussion}

The results of these experiments show that immunisation of sows with an antigenic extract of Escherichia coli may lead to sensitisation of their piglets whether or not the piglets have acquired antibody from colostrum. Similar results were observed in earlier experiments (Shreeve and Thomlinson, 1970a) in which egg albumin was employed as the antigen for immunisation and challenge, except that when piglets from normal sows were challenged with egg albumin completely negative results were obtained. In the present experiments, however, the reactions that developed in piglets from normal sows were not unexpected because the sows had been exposed previously to $E$. coli $\mathrm{O} 138$ : K81(B). This organism was, on occasion, present in their faeces and antibodies were detected in serum samples. In general, the results of the present experiments followed a similar trend to those of the earlier experiments with egg albumin. In the colostrum-deprived piglets from the immunised sows, 
the skin reactions developed earlier and were more severe than in those from normal sows. Similarly, reactions after intravenous challenge developed immediately and generally were more severe. The most severe reactions were observed in some of the colostrum-fed piglets from the immunised sows. Two of these piglets, however, failed to develop signs after intravenous challenge although they had shown the most severe skin reactions. These piglets had high serum antibody titres, but others with similar titres showed severe signs. It may be that, for a given challenge dose of antigen, a very narrow margin exists between the level of circulating antibody necessary for protection and the amount that will allow severe shock to take place. There is also a possibility that fixation of antibody may not have been optimal at the time of challenge or that the severe dermal reactions that developed in these piglets may have led to desensitisation.

In the present experiments, and in the earlier work in which egg albumin was used (Shreeve and Thomlinson, 1970a), neutrophils were the only infiltrating cell-type observed in skin reactions in piglets from normal sows and colostrumdeprived piglets from immunised sows whereas, in the colostrum-fed piglets from the immunised sows, infiltrating lymphocytes and eosinophils were noted. In the present experiments, macrophages were also observed in these lesions in colostrum-fed piglets from immunised sows. The presence of macrophages is probably consistent with the higher levels of circulating antibody in these piglets. Gell and Hinde (1954) found that, in Arthus reactions, polymorphs were replaced by mononuclear cells, mostly lymphocytes and monocytes, after a period of $8 \mathrm{hr}$.

The significance of the various lesions that developed when piglets were challenged by intravenous injection has already been discussed (Shreeve and Thomlinson, 1970a). The most striking features were the oedematous lesions that occurred in the present experiments as well as in those in which egg albumin was used. Similar lesions are common in E. coli disease of young piglets (Shreeve and Thomlinson, 1970b) and they also occur in anaphylactic shock (Thomlinson and Buxton, 1963) and in oedema disease associated with E. coli in weaned pigs (Timoney, 1950, 1956; Ohshima and Miura, 1961; Thomlinson and Buxton, 1962). Oedematous lesions affecting the greater curvature of the stomach were absent in the two piglets that were killed $1 \mathrm{hr}$ after challenge and it is possible that differences in the distribution of these lesions may depend partly on the stage in the disease process at which death occurs and partly on the severity and duration of the anaphylactic reaction (Thomlinson and Buxton, 1963). In orally infected piglets, Kohler and Bohl (1966) found that gross enteritis was absent in the acute phase of the disease; it is noteworthy that gross lesions of the gastro-intestinal mucosa were not observed in the present experiments and were not a constant finding in experimental anaphylaxis with egg albumin (Shreeve and Thomlinson, 1970a) or in naturally occurring $E$. coli disease (Shreeve and Thomlinson, 1970b).

Mechanisms that could lead to the development of hypersensitivity in young piglets have already been postulated (Shreeve and Thomlinson, 1970a). In the present experiments, it is possible that the administration of $E$. coli antigen 
a short time before parturition may have caused placental damage and led to the transfer of maternal antibody to the piglets in utero (Kim, Bradley and Watson, 1966). A similar process may occur under natural conditions when sows are subjected to routine changes of husbandry before parturition (Shreeve and Thomlinson, 1971). On the other hand, it is possible that sensitisation could occur as a result of active antibody production by the foetus (Binns, 1967). Moreover, antibody acquired from colostrum may cause sensitisation. The presence of circulating antibody may confer protection against a given challenge dose of $E$. coli endotoxin, but it is possible that anaphylactic shock may occur if this dose is exceeded by only a small amount. This observation suggests that the use of $E$. coli vaccines in pregnant sows may not be an effective prophylactic measure in all circumstances.

Buxton and Thomlinson (1961) postulated from the results of their investigations into oedema disease of weaned pigs that the majority of pigs become hypersensitive to $E$. coli and that the absorption of relatively large quantities of bacterial polysaccharide from the intestines, resulting from a sudden multiplication of $E$. coli, leads to a state of anaphylactic shock with the characteristic signs and lesions. Stevens (1963) suggested that, although a shock phenomenon may play a part in the older pig, $E$. coli disease of young piglets is probably the result of direct infection. However, the similarity of the lesions (Shreeve and Thomlinson, 1970b) suggests that the disease process may be caused by a similar mechanism in both age-groups. The present experiments have shown not only that young piglets may be hypersensitive to $E$. coli at birth or after they have received colostrum but also that $E$. coli endotoxic extract administered by the oral route is absorbed rapidly and can cause a shock reaction. These findings lead to the conclusion that anaphylaxis may play a part in the pathogenesis of E. coli disease in the young piglet as well as in the older pig.

\section{SUMMARY}

Colostrum-deprived and normally suckled piglets from normal sows and from sows immunised with an extract of Escherichia coli 0138:K81(B) were challenged with the same endotoxic extract preparation by the dermal, intravenous and oral routes. Reactions were more severe in piglets from immunised sows, and lesions were similar to those seen in field outbreaks of E. coli disease. It is postulated that such lesions may be immunological in origin, and that anaphylactic shock may be important in the pathogenesis of $E$. coli disease in baby piglets.

We wish to acknowledge the financial support of the Pig Industry Development Authority. Our thanks are due to Professor D. L. Hughes for helpful advice. We are grateful to Mrs M. W. Harling for technical assistance and to Mr G. Weston for the photomicrographs.

\section{REFERENCES}

BINNS, R. M. 1967. Bone marrow and lymphoid cell injection of the pig foetus resulting in transplantation tolerance or immunity, and immunoglobulin production. Nature, Lond., 214, 179. 
Buxton, A., AND Thomlinson, J. R. 1961. The detection of tissue sensitizing antibodies to Escherichia coli in oedema disease, haemorrhagic gastro-enteritis and in normal pigs. Res. Vet. Sci., $2,73$.

ERsKine, R. G., SoJKA, W. J., AND Lloyd, M. K. 1957. The experimental reproduction of a syndrome indistinguishable from oedema disease. Vet. Rec., 69, 301.

Gell, P. G. H., AND HINDE, Isobel T. 1954. Observations on the histology of the Arthus reaction and its relation to other known types of skin hypersensitivity. Int. Archs Allergy Appl. Immun., 5, 23.

KIM, Y. B., BRADLEY, S. G., AND WATSON, D. W. 1966. Ontogeny of the immune response. I. Development of immunoglobulins in germfree and conventional colostrum-deprived piglets. J. Immun., 97, 52.

KoHLER, E. M., AND BoHL, E. H. 1966. Studies of Escherichia coli in gnotobiotic pigs. I. Experimental reproduction of colibacillosis. Canad. J. Comp. Med., 30, 199.

OHshimA, K., AND MIURA, S. 1961. Pathological study on an occurrence of swine edema disease in Iwata prefecture in 1959. Jap. J. Vet. Sci., 23, 111.

ShreEve, B. J., AND ThOMLINSON, J. R. 1970a. Hypersensitivity in young piglets: its relation to the pathogenesis of Escherichia coli disease. J. Med. Microbiol., 3, 377.

Shreeve, B. J., AND Thomernson, J. R. 1970b. Escherichia coli disease in the piglet. A pathological and bacteriological investigation. Br. Vet. J., 126, 444.

Shreeve, B. J., AND Thominson, J. R. 1971. Bacteriological and serological studies in preparturient sows. Br. Vet. J., 127, 57.

STEVENS, A. J. 1963. Coliform infections in the young pig and a practical approach to the control of enteritis. Vet. Rec., 75, 1241.

Thomlnson, J. R., AND Buxton, A. 1962. A comparison of experimental anaphylactic shock in guinea-pigs with naturally-occurring oedema disease and haemorrhagic gastroenteritis in pigs. Res. Vet. Sci., 3, 186.

Thomlinson, J. R., AND Buxton, A. 1963. Anaphylaxis in pigs and its relationship to the pathogenesis of oedema disease and gastro-enteritis associated with Escherichia coli. Immunology, 6, 126.

Timoney, J. F. 1950. Oedema disease of swine. Vet. Rec., $62,748$.

Timoney, J. F. 1956. Oedema disease of swine. Vet. Rec., 68, 849. 